\title{
UJI EKSTRAK DAUN ALOCASIA MACRORRHIZOS SEBA GAI ANTIBAKTERI TERHADAP PERTUMBUHAN ESCHERICHIA COLI DAN STAPHYLOCOCCUS AUREUS SECARA IN VITRO
}

*Hamtini, *Syarah A, *Shufiyani

\begin{abstract}
Abstrak
Antibakteri adalah subtansi kimia yang dihasilkan oleh mikroba dan dapat menghambat pertumbuhan mikroba lain, pada saat ini dikenal dengan istilah antibiotik. Namun, penggunaan antibiotik yang kurang tepat dapat menyebabkan adanya resistensi antibiotik. Penemuan berbagai senyawa obat baru dari bahan alam semakin memperjelas peran penting metabolit sekunder tanaman sebagai sumber bahan baku obat. Penelitian ini bertujuan untuk mengetahui aktivitas antibakteri pada ekstrak metanol daun Alocasia macrorrhizos. Ekstrak metanol daun kemudian dilakukan dengan uji fitokimia. Uji aktivitas antibakteri menggunakan metode difusi agar, bakteri uji yang digunakan adalah Escherichia coli dan Staphylococcus aureus. Konsentrasi yang digunakan untuk uji aktivitas antibakteri adalah $40 \%, 20 \%, 10 \%$, dan 5\%. Untuk kontrol positif, digunakan antibiotik tetraxiclin $1 \%$. Sedangkan, hasil uji fitokimia didapatkan komponen-komponen senyawa seperti flavonoid, tanin, dan steroid. Hasil uji aktivitas antibakteri didapatkan diameter zona hambat tertinggi pada konsentrasi 40\% sebesar 3,7 mm untuk Staphylococcus aureus dan untuk Escherichia coli diameter zona hambat tertinggi pada konsetrasi $40 \%$ sebesar 2,56 mm.
\end{abstract}

Kata kunci: ekstrak, daun Alocasia macrorrhizos, antibakteri, Escherichia coli dan Staphylococcus aureus

*) Dosen Jurusan Analis Kesehatan Poltekkes Kemenkes Banten 


\section{Pendahuluan}

Menurut Depkes (2007) baru sekitar 9.600 tanaman yang diteliti khasiatnya sebagai obat dan kurang lebih 300 tanaman telah digunakan sebagai bahan obat tradisional oleh industri obat tradisional. Akhir-akhir ini kencenderungan dalam penggunaan obat tradisional sebagai pilihan untuk pengobatan menjadi alternatif yang banyak diminati karena obat tradisonal terbukti relatif aman dengan cara penggunaan yang benar dan indikasi yang tepat serta jarang sekali menimbulkan efek samping (Nanik, 2006).

Tanaman Araceae merupakan tanaman yang diduga memiliki kandungan yang diantaranya adalah flavonoid dan saponin (Biren et al. 2007). Salah satu golongan tanaman Araceae adalah tanaman Alocasia macrorrhizos biasa dikenal dengan tanaman sente. Tanaman ini tumbuh liar di daerah tropis. Tanaman ini memiliki daun berbentuk perisai, warna daun yang sangat bervariasi tergantung varietasnya, dan tumbuh hingga 1,2-1,8 m diketinggian dibawah kondisi yang menguntungkan. Tanaman ini sering digunakan sebagai tanaman hias di perkarangan rumah. Tanaman ini mengandung flavonoid, cynogenetik, glikosida, asam askorbat, asam galat, asam malat, asam oksalat, asam suksinat dan $\beta$ lektin (Rahman et al. 2012). Menurut (Srivastava et al. 2011) bahwa pada batang tanaman Alocasia macrorrhizos dapat berguna sebagai antifungal, analgesik, antitumor dan antioksidan.

Ekstraksi adalah istilah dalam bidang farmasi yang artinya pemisahan bahan aktif baik pada tanaman maupun hewan dengan menggunakan pelarut selektif sesuai standar prosedur ekstraksi. Standarisasi proses ekstraksi bertujuan untuk memurnikan zat aktif dari zat lain dengan menggunakan pelarut tertentu (Constantine 2007). Pemilihan metode ekstraksi sangat penting dilakukan karena hasil ekstraksi akan menunjukkan tingkat keberhasilan metode tersebut dalam mengeluarkan senyawa metabolit sekunder dari matriks bahan ke dalam pelarut (Salas et al. 2010).

Berdasarkan uraian latar belakang tersebut sehingga perlu dilakukan penelitian tentang pemanfaatan ekstrak daun Alocasia macrorrhizos sebagai antibakteria yang dapat menghambat pertumbuhan Escerichia coli dan Staphylococcus aures secara in vitro. 


\section{Metode Penelitian}

Jenis penelitian yang dilakukan adalah eksperimen, dengan melakukan uji aktivitas antibakteri pada ekstrak daun Alocasia macrorrhizos. Bakteri yang digunakan dalam penelitian ini yaitu bakteri Escherichia coli dan Staphylococcus aureus.

\section{Hasil}

\section{Aktivitas Antibakteri ekstrak daun Alocasia macarrizos}

\section{S.aureus}

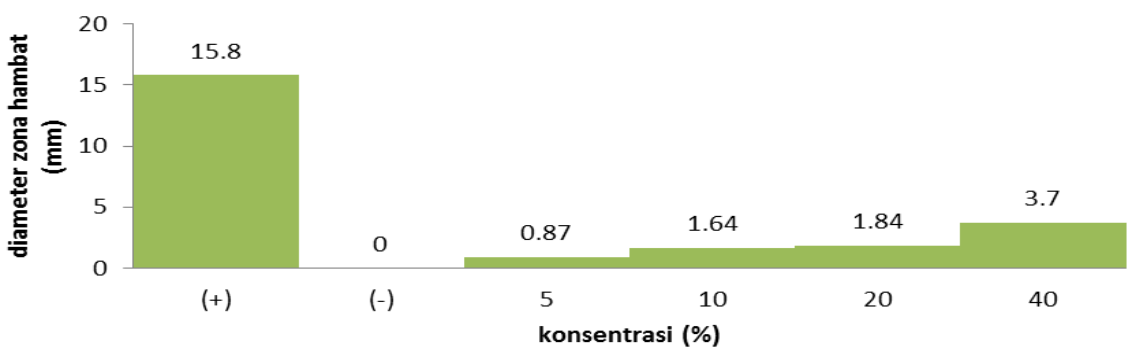

Gambar 1. Diameter zona hambat bakteri Staphylococcus aureus terhadap ekstrak metanol daun Alocasia macarrizos

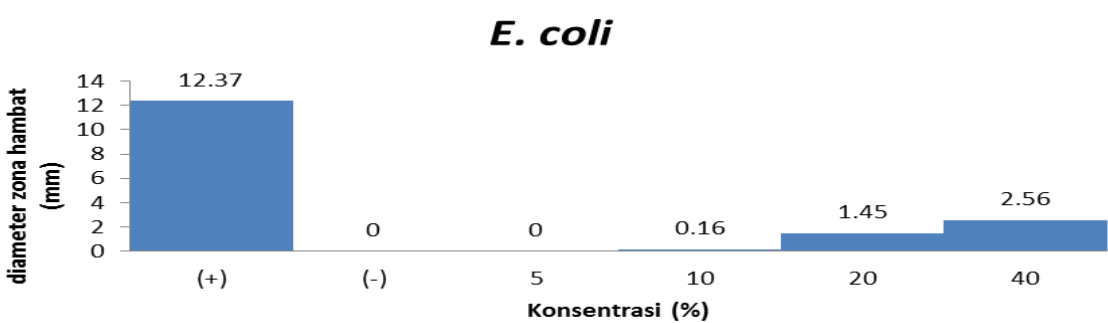

Gambar 2. Diameter zona hambat bakteri E.coli terhadap ekstrak metanol daun Alocasia macarrizos

\section{Pembahasan}

Ekstraksi dilakukan menggunakan metode maserasi dan pelarut yang di gunakan adalah metanol. Hasil uji fitokimia menunjukkan bahwa ekstrak daun Alocasia macarrizos mengandung senyawa flavonoid dan tanin yang dapat berpotensi sebagai antibakteri. Menurut Sabir (2005) disebutkan bahwa flavonoid menyebabkan terjadinya kerusakan permeabilitas dinding sel bakteri, mikrosom dan lisosom sebagai hasil interaksi antara flavonoid dengan DNA 
bakteri. Flavonoid merupakan senyawa yang memiliki sifat antibakteri. Menurut Karlina et al. 2013 dinding bakteri yang terkena flavonoid akan kehilangan permeabilitas sel.

Tanin merupakan senyawa pofipenol yang mengandung cukup banyak gugus hidroksil dan gugus lain serta dapat membentuk kompleks dengan protein dan makromolekul lain (Harborne 2006). Senyawa metabolit sekunder berupa tanin juga dapat bersifat sebagai antibakteri. Tanin memiliki peran sebagai antibakteri dengan mengikat protein sehingga pembentukan dinding sel akan terhambat (Karlina et al 2013).

$\begin{array}{rrrr} & \text { Aktivitas } & \text { antibakteri terhadap } \\ \text { bakteri uji } & \text { ditunjukkan dengan }\end{array}$ terbentuknya zona hambat atau zona bening di area cakram. Pengujian aktivitas antibakteri ini dilakukan untuk mengetahui potensi antibakteri dari ekstrak daun Alocasia macarrizos. Bakteri uji yang di gunakan adalalah Staphylococcus aureus termasuk ke dalam bakteri Gram positif dan Escherichia coli termasuk ke dalam bakteri Gram negatif. Setelah dilakukan uji aktivitas antibakteri dengan metode difusi agar di dapatkan diameter zona hambat tertinggi di konsentrasi $40 \%$ sebesar 3,7 $\mathrm{mm}$ untuk Staphylococcus aureus dan diameter zona hambat tertinggi untuk Escherichia coli adalah sebesar 2,56 mm pada konsentrasi 40\% (Gambar 1, dan 2).

Berdasarkan data tersebut dapat diketahui bahwa ekstrak daun Alocasia macarrizos dengan menggunakan pelarut metanol di dapatkan hasil uji aktivitas antibakteri termasuk dalam kategori lemah. Menurut ketentuan kekuatan antibakteri yang dikemukan oleh David Scout, kategori lemah di golongkan jika diameter zona bening yang terbentuk $\leq 5 \mathrm{~mm}$, kategori sedang pada kisaran 5-10 mm, dan kategori kuat jika diameter zona bening yang terbentuk $\geq 10 \mathrm{~mm}$ (Lathifah 2008). Hal ini kemungkinan di karenakan konsentrasi ekstrak yang digunakan masih belum tepat sehingga hasil atau diameter zona hambat yang di dapatkan dalam kategori lemah.

\section{Simpulan}

Hasil uji aktivitas antibakteri di dapatkan diameter zona hambat dari kedua bakteri yang di ujikan yaitu paling besar pada konsetrasi $40 \%$ dengan diameter 3,7 mm untuk S.aureus dan 2,56 mm untuk E.coli dengan konsetrasi yang sama. 


\section{Daftar Pustaka}

[Depkes RI] Departemen Kesehatan Republik Indonesia. 2007. Kebijakan Obat Tradisional Nasional. Jakarta (ID): Departemen Kesehatan Republik Indonesia.

Biren, N.S., Nayak, B.S, Bhatt, S.P, Jalalpure., S.S., Seth., A.K. 2007. The Anti-imflamatory activity of The Leaves of Colocasia esculenta. SPJ, Vol. 15. 3-4

Constantine SD. 2007. Extraction, separation, and detection methods for phenolic acids and flavonoids. $J$. Sep. Sci. 30: 3268 - 3295.

Harborne JB. 2006. Metode Fitokimia. Penerjemah: Patmawinata $\mathrm{K}$ dan Soediro I. Edisi Kedua. Bandung (ID): Penerbit ITB.

Lathifah QA. 2008. Uji ekfektivitas ekstrak kasar senyawa antibakteri pada buah belimbing wuluh (Averhoa bilimbi L.) dengan variasi pelarut [Skripsi]. Malang (ID): Universitas Negeri Islam Negeri Malang.

Karlina CY, Ibrahim M, Trimulyono G. 2013. Aktivitas antibakteri ekstrak herba Krokot (Portulaca oleracea L.) Terhadap Staphylococcus aureus dan Escherichia coli. Lentara Bio. 1(1): 87-93

Krenawaty I, Zainuddin A. 2009. Aktivitas antioksidan dan antibakteri dari derivat metil ekstrak etanol daun gambir (Uncaria Gambir). J. Littri. 15(4): 145-151.

Nanik Fauziah. 2006. Isolasi dan Uji Aktifitas Inhibitor Xantin Oxidase Senyawa Flavonoid dari Kulit Batang Saccopetalum Horsfledii Benn. Library@ lib.unair.ac.ic.

Rahman, Masudur., Hossain, Aslam., Alam, Saiful Siddique, Parvej, Kaishar BIPLAB, Uddin, Helal. 2012. Antihyperglycemic, antioxidant, and, cytotoxic activities of Alocasia macrorrhizos (L) rhizome extract. Turk J Biol. 36: 574 $-579$

Sabir A. 2005. Aktivitas antibakteri flavonoid propolis Trigona $\mathrm{sp}$. terhadap bakteri Streptococcus mutans (in vitro). Majalah Kedokteran Gigi 38(3):135-141.

Salas PG, Aranzazu MS, Antonio SC, Alberto FG. 2010. PhenolicCompound- Extraction Systems for 
Fruit and Vegetable Samples.

Molecules. 15: 8813-8826.

Srivastava, Vivek, Mubeen, Sheikh, Chand, Bhupesh Semwal, Misra, Vimlesh. 2012. Biological Activities Of Alocasia Macrorrhiza : a Review. Journal of Science. ISSN- 2277 - 18 